\title{
Council Session in Vienna
}

On 14 July 1969, a session of the Council of the European Physical Society was held at the headquarters of the International Atomic Energy Agency (IAEA) in Vienna. Important decisions were taken concerning the definition of Associate Membership, the formation of the first Specialized Divisions of the Society, and the rules governing Advisory Committees and Divisions. These decisions are covered in the following report.

The meeting was attended by 32 of the 51 delegates representing Individual Ordinary Members, National Physical Societies, Groups and Laboratories. In addition, there were three invited delegates from National Societies. As G. Bernardini, President of the Society, remarked in his introduction, the Vienna meeting was really the first working session of the Council; in Florence, the Council was constituted and had met for only a brief session mainly to elect the Executive Committee and to adopt the By-laws in a preliminary form. He said that important decisions were now needed so that the Society could start to function as an effective instrument for the promotion of physics in Europe.

\section{Membership of the Society}

The Council first discussed criteria concerning membership as defined in the Constitution under categories $4 a$ and $4 \mathrm{c}$ (Individual Ordinary Members) and $4 \mathrm{~b}$ (National Physical Societies, National Academies, Groups or Laboratories). At present, there are 588 Individual Members and it is regarded as essential that a large number of physicists join the EPS as Individual Members. It was emphasized once again that individual membership (category $4 c$ ) is open also to members of National Physical Societies etc. at a substantially reduced membership fee. A concentrated effort must be made to interest as many physicists as possible in direct participation in the activities of the EPS.
Regarding membership category $4 b$, the Council felt that Groups or Laboratories residing in countries where there exists a strong National Society or Academy which is itself already a member, should not be encouraged to apply for membership under category 4b. Instead, physicists from such Groups or Laboratories could join as individual members under categories $4 \mathrm{a}$ or $4 \mathrm{c}$. Their Organisation could also apply for Associate Membership.

Individual members will be accepted by Council every three months. If there is no meeting during such a period, the acceptance procedure will be carried out by mail.

Associate Membership was discussed by the Council and the results of the discussion are given in Society News (page 3). Whereas Ordinary Membership is defined in the Constitution and By-laws, the definition of Associate Membership had so far been left undetermined. In order to attain its goals, the European Physical Society must be able to count on the active support and advice of a broad section of modern society. In particular, the interest of the large research laboratories and of industry will be extremely valuable. Associate Membership is an appropriate way to establish this desirable liaison. Associate Members will receive several benefits and participate actively in the affairs of the Society. The Council emphasized the importance of this type of membership, which makes it possible for many organisations to associate themselves with the Society.

\section{Formation of first Specialized Divisions}

In order to get the activities of the EPS under way in the different domains of physics, it was felt necessary to take decisions of principle concerning Specialized Divisions of the EPS. Several requests had been received by groups of physicists, some of which already had well-defined and active programmes of conferences and co- ordination of research. The principal issue was whether these groups as such should be accorded the status of a Division of the EPS, or whether Divisions should be formed only after a complete framework of Divisions had been worked out.

After long debate, the Council decided that those requests received with the backing of active groups of physicists should be accepted and the formation of the corresponding Divisions approved on a preliminary basis. In two years the Council will review the situation and make changes, if appropriate. The following Specialized Divisions (described in the articles beginning on page 7) were then constituted:

- Atomic Spectroscopy Division (Chairman: A. Kastler, Paris)

- Condensed Matter Division (Chairman: S.F. Edwards, Manchester)

- Low-Temperature Physics Division (Chairman: J. de Boer, Amsterdam)

- Plasma Physics Division (Chairman: B. Lehnert, Stockholm)

- Quantum Electronics Division (Chairman: K.P. Meyer, Berne).

\section{General rules concerning Divisions}

Following Article 2.2 of the Constitution which states, "In order to fulfil its purpose, the Society shall act either directly or through its members or through specialized divisions created by its members...", the Executive Committee is empowered (in Article 20f) to "sponsor and supervise special divisions organized within the Society by its members in accordance with the By-laws".

The By-laws concerned with Specialized Divisions are:

Rule 29: The formation of a Specialized Division may be approved by the Council on receipt of a formal request from not less than five Ordinary Members.

Rule 30: Participation in the Activities of Specialized Divisions shall be restricted to Individual Ordinary Members 
and Fellows of the Society and to members of such societies, groups or laboratories as are Ordinary Members of the Society.

It is understood that representatives of Associate Members will also be invited to participate in Divisional activities. Ed.

Rule 31: The rules and regulations governing each Specialized Division shall be approved by the Council.

Rule 39: Membership of a Specialized Division shall not involve any additional fee to the Society.

In addition to these regulations, the following general rules were adopted by the Council:

1. A Division shall cover an active field of physics or a combination of related active fields. Its activities shall comprise:

a) promoting the co-ordination of research activities in the field in Europe, wherever possible;

b) organizing topical conferences;

c) furthering the exchange of research scientists and students.

2. The affairs of a Division shall be conducted by a committee of European composition, consisting of Individual Ordinary Members or Fellows of the EPS and including a Chairman and a Secretary confirmed by the Executive Committee.

3. The Committee of a Division shall report to each meeting of the Executive Committee and of the Council.

\section{Advisory Committees to the Executive Committee}

The rules of operation for Advisory Committees and the rules concerning membership of such Committees were also discussed by the Council. These Committees help the Executive Committee in special tasks.

Two such Committees have been in existence for some time, namely the Publications Committee under the chairmanship of $\mathrm{J}$. de Boer (a summary of its activities can be found in Europhysics News No. 2) and the Conference Committee under the chairmanship of G.H. Stafford (a summary of its activities can be found in Europhysics News No. 3).

A large number of physicists recently proposed to the Executive Committee the creation of an Advisory Committee on Physics and Industry: it would advise the Executive Committee on all matters regarding the development of physics in Europe tending in particular towards its applications. For example, the Committee would stimulate the organization of physics conferences with emphasis on applications. In a circular letter from the Secretary of the EPS, the National Physical Societies and Academies have been asked to propose names for membership of this Committee and its official constitution is expected in autumn 1969.

A particularly important activity of the EPS lies in the field of education of young physicists in Europe. In this connection the Executive Committee has set up an Advisory Committee on Summer Schools and Student Exchanges to start work as soon as possible. This Committee should also help to centralize information regarding Fellowships available at different Institutes in Europe. (To assist this Committee, the EPS Secretariat in Geneva would greatly appreciate receiving all relevant information.)

Another request has been received, supported by many outstanding scientists, to create an Advisory Committee on Physics and Society. This subject is very broad and complex, but the need for engagement on the part of the EPS appears evident. A preparatory study should precede the start of activities in special domains and at the end of this study, the Study Group will report to the Executive Committee with recommendations on what the aims of the EPS should be within a realistic appraisal of the likely resources of the EPS during the next few years, and on what means might be adopted to achieve these aims. The formation of this Study Group is expected during autumn 1969.

\section{Rules of operation for Advisory Com- mittee}

The following rules were accepted by the Council:

Rule 1: The Executive Committee may create Advisory Committees (1) for specialized tasks, (2) to cover special fields of physics, (3) to promote and protect certain common interests or aspects in different fields.

Rule 2: Task and duration of any Advisory Committee are specified by the Executive Committee.

Rule 3: Members of Advisory Committees shall all be either Individual Ordinary Members of the Society or delegates of Members 4b). The Members of the Committee and the Chairman are appointed by the Executive Committee.

Rule 4: Advisory Committees report to the Executive Committee. A report on every meeting of the Advisory Committee approved by its members shall be sent to the Executive Secretary of the Society. Consequently the Chairman of an Advisory Committee may be invited to attend Executive Committee meetings.
Rule 5: Members of an Advisory Committee will serve for a maximum of five years.

Rule 6: All members of an Advisory Committee, when speaking about, or in connexion with, matters regarding which they have financial or other relevant commitments, must state the nature and extent of such commitments.

Rule 7: Chairmen of Advisory Committees may be invited to attend meetings of the Council without voting rights.

\section{Rules of membership for Advisory Committees}

The following rules were accepted by the Council as guide-lines (they are not meant to be strictly binding as it is more important to retain the necessary flexibility to adapt membership to specific tasks):

The membership of an Advisory Committee should be properly representative. Effectiveness requires, on the other hand, that the Committee should not be too large; it is felt that a membership of about 15 is optimal.

In addition to a Chairman there should be in principle:

a) At least one member of each board of all relevant Specialized Divisions, to be proposed by the respective board. b) One representative from each of the large National Physical Societies or Academies with considerable activity in the field considered by the Committee and an adequate number of representatives of the smaller $\mathrm{Na}$ tional Physical Societies, Groups or Laboratories.

c) One representative of Individual Ordinary Members.

d) One representative of the International Union of Pure and Applied Physics.

e) The Executive Secretary of the European Physical Society or a representative should be present.

f) A minimum of one member from the Council of the European Physical Society.

\section{Future of Europhysics News}

It was decided at the Steering Committee Meeting in Prague (3, 4 May 1968), following a proposition of the Working Group on Publications, to publish a small scale Bulletin of the EPS, until the end of 1971. This Bulletin was given the name "Europhysics News". In order to move to a full-size journal in 1972, it is necessary to start planning now.

G.J. Béné (Geneva) presented a paper on the general scope, contents 